Article

\title{
House Demolitions
}

\section{Mordechai Kremnitzer ${ }^{1,2}$ and Lina Saba-Habesch ${ }^{2,3, *}$}

1 Faculty of Law, Hebrew University of Jerusalem, Har ha-Tsofim, Jerusalem 9190501, Israel

2 The Israel Democracy Institute, Pinsker Street, Jerusalem 92228, Israel; E-Mail: motak@idi.org.il

3 Faculty of Law, Freie Universität Berlin, Kaiserswerther Straße 16-18, Berlin 14195, Germany

* Author to whom correspondence should be addressed; E-Mail: lina@idi.org.il.; Tel.: +972-2530-0876; Fax: +972-2530-0837.

Academic Editor: Robert Johnson

Received: 27 January 2015 / Accepted: 13 May 2015 / Published: 29 May 2015

\begin{abstract}
This article discusses the nature of "house demolitions" as used by the State of Israel in the West Bank and East Jerusalem. In our opinion, and in contrast to the view of Israel's Supreme Court, such demolition orders constitute a penal sanction. As a penal sanction, we argue that this measure violates the basic principles of criminal liability. Even if this conclusion is not accepted, it will be argued that making innocent people homeless is an illegal collective measure. Even if assuming arguendo that it is not an illegal collective measure, it violates the basic principle of personal responsibility. The general conclusion of the article is that the examination of the nature of sanctions should go beyond the labels that are attached to them. Labeling sanctions as either penal or civil may not always reflect its true nature, and labels are sometimes deliberately used or rather misused in order to escape from the requirements stemming from the true essence of a sanction.
\end{abstract}

Keywords: house demolition; penal sanction; personal culpability; collective punishment; deterrence

\section{Introduction}

"House Demolitions" is a measure used by Israel in the West Bank and East Jerusalem in cases of participation (or suspicion of participation) of one of the house's residents in a terrorist act. Israel 
has implemented house demolitions since its military occupation of the West Bank and Gaza ([1], pp. 871, 884). In times of escalation, the military has used this measure frequently ${ }^{1}$.

House demolitions are carried out under Article 119 of the Defense Emergency Regulation ([2], art. 119) (Hereinafter: Article 119) ${ }^{2}$, which is part of a British Emergency Legislation enacted in $1937^{3}$ in response to acts of terrorism committed by Arab and Jewish organizations ([3], pp. 359, 361).

A military commander determines whether to demolish or seal any house in Israel or in the Occupied Territories. Article 119 grants the commanders a wide discretion to make their decision: They may decide to demolish a house before the suspect's conviction, solely based on the suspicion that one of the residents of the house has committed a crime ([1], p. 889) ${ }^{4}$. This applies even when the crime is a relatively minor one ([1], p. 886; [4], pp. 1,17$)^{5}$, such as intimidation or aiding after the commission of an offense ([2], art. 64). They may issue the order at the time when the suspect was killed (a suicide bomber for example) ([1], p. 886), and also while the suspect's family or extended family live in the same house. The measure may also be used in cases where the inhabitants of the house were completely unaware of the offender's actions ([1], p. 889; [5], p. 313). In addition, since Article 119 makes no reference to the question of ownership of the house, the commander may decide to demolish a house even when the suspects and their family are only tenants and the owners themselves have no connection to the offense ([4], p. 17). Moreover, the demolition sanction may be enacted in addition to any another judicial sanction that might be imposed on the suspects after their conviction.

Prior to 1979, demolitions were executed immediately after the military commander's decision, without the involvement of the Israeli Supreme Court, since the residents did not have time to petition against the decision ${ }^{6}$. Since 1979 , the residents of the house receive prior notice and can petition the decision to the court ([4], pp. 28-32; [6]). As a result, the Supreme Court became much more involved in these measures. It is empowered to review, cancel or modify a demolition order. Nonetheless, in practice, most of the petitions against demolitions orders are rejected and the Supreme Court rarely cancels demolition orders ([7], pp. 251, 265).

1 Escalation happened, for example, during the first and second intifadas (1987-1991, 2000-2005), and during the recent deterioration in Arab-Israeli relations (2014).

2 "A Military Commander may by order direct the forfeiture the Government of Palestine of any house, structure, or land from which he has reason to suspect that any firearm has been illegally discharged, or any bomb, grenade or explosive or incendiary article illegally thrown, or of any house, structure or land situated in any area, town, village, quarter or street the inhabitants or some of the inhabitants of which he is satisfied have committed, or attempted to commit, or abetted the commission of, or been accessories after the fact to the commission of, any offence against these Regulations involving violence or intimidation or any Military Court offence; and when any house, structure or land is forfeited as aforesaid, the Military Commander may destroy the house or the structure or anything growing on the land."

3 The legislation was enacted when Great Britain administered Palestine under a mandate arrangement with the League of Nations. Besides demolition of houses, the defense regulation includes other broad powers such as detention, expulsion, and confiscation of property without a fair procedure.

4 In practice, the commander rarely waits until the suspect is convicted in court to carry out the demolition. Most of the demolitions take place right after the suspect's arrest, and in some cases even before their arrest.

5 Article 119 does not set a standard regarding the severity of the offense that must be met. Thus, it gives the commander almost limitless authority in determining the circumstances in which they can order home demolition. Nonetheless, the military normally employs it only in serious cases.

6 The option to petition the decision was only available for a few hours, making it practically impossible to implement. 
In 2005, based on the recommendations of a committee of high ranking Israeli Defense Force (Hereinafter: IDF) officers - the Shani Committee - it was decided to freeze the policy. The committee doubted the policy's legality, morality, and effectiveness. Following the report of the Shani Committee, the Minister of Defense decided to end the use of the house demolitions measure until a drastic change of circumstances occurred which would allow them to reinstate it. In 2008, following terror attacks by individuals not connected to any specific terroristic organization ${ }^{7}$, the Israel Security Agency (Hereinafter: ISA) considered this a drastic change in circumstances. The court approved the ISA decision and the demolitions were reinstated ([8], pp. 363, 375-76).

We do not know the exact number of houses that have been demolished, but it is reasonable to assume that it exceeded one thousand demolitions ([9], pp. 477-80).

The house demolitions measure has a devastating impact on the lives of the residents of these houses. A house is not merely someone's property; it also represents memories, history, identity and link to the land, personal belongings, status, family and tradition. Overnight, their entire lives change; family members find themselves roofless, homeless, humiliated, and living in tents without an option to go back to their previous lives. The demolition result is particularly devastating in cases where the family cannot afford alternative housing, as is the case in many of the demolitions cases ([3], p. 373).

The demolition measure raises several problems. In this article we shall focus on the nature of this measure, and on whether it is an administrative preventive measure or a punitive one. If it is punitive, it has to fulfill the domestic and the international conditions for applying a punishment. These conditions include among others: personal responsibility, that the punishment must be issued by a judicial authority after a fair trial, and that it should be considered a legitimate measure as opposed to an inhuman and cruel one.

In our view, demolition orders constitute a penal sanction. As a penal sanction, it violates the basic principles of criminal liability. Even if this conclusion is not accepted, it will be argued that making innocent people homeless is a collective measure. Even if it is not considered a collective measure, the measure violates the basic principle of personal responsibility ([3], p. 361).

\section{A Problematic Measure}

The demolition measure is problematic and raises several issues that exceed the scope of this article. We shall mention the most significant ones briefly:

A. Effectiveness-The main justification for the policy of house demolitions is deterrence. According to this justification, those who have not yet committed an offence of terrorism will acknowledge its harsh consequences and will refrain from committing it. In addition, people who live with a potential suspect will try to prevent them from committing the crime or report them to the authorities ([5], p. 320). One important issue that rises from this justification is the measure's effectiveness. This is a complex issue, without any clear consensus. In a nutshell, even if we assume that the measure is in fact effective in creating deterrence, it is clear that

7 In such circumstances, early detection through intelligence was impossible, hence the increased need for deterrence. 
because of its unjust character $([4], \text { p. } 13 ;[10])^{8}$, it also engenders hatred toward the authorities and encourages acts of revenge and violent responses. Member of Knesset Amnon Rubinstein also criticized the effectiveness of the measure and stated: "You can blow up one more home, you can blow up ten more homes - it just won't do any good" ([4], p. 14; [11]). According to this approach, the harm that the policy creates exceeds its benefits ([4], p. 14; [7], p. 269) ${ }^{9}$.

B. Property Rights - The demolition measure also violates the property rights of residents' of occupied territories under international law. Article 53 of the Fourth Geneva Convention [12] states that "Any destruction by the occupying power of real or personal property belonging individually or collectively to private persons is prohibited, except where such destruction is rendered absolutely necessary by military operations" (emphasis added). Punitive demolition of houses for deterrence purposes is not related to a "military operation" and is not absolutely necessary, and is therefore prohibited under international law ([3], pp. 371-72; [13]) ${ }^{10}$. The premise of this article is that the human rights law continue apply in non-international armed conflict as well as international conflict, including situation of occupation. the UN human rights committee ([14], pp. 310, 324, 326) and the International Court of Justice [15] confirmed this approach (although Israel's government formal approach opposes the application of human rights law in times of conflict, in practice, the Supreme Court in its decisions applies human rights law extraterritorially in the occupied territories [16]. Therefore, the government objection does not reflect the state practice [14].

C. Discrimination-Demolitions have been used solely against Palestinians' houses, and no demolitions have been carried out against Jewish settlers in the West Bank and Gaza or against the homes of Jews' within Israel who committed acts of terrorism, despite the fact that Article 119 applies also in Israel. It seems that the use of this sanction was not even considered in such cases, since the measure is only seen as fit for treating the "other", and not for Jewish Israeli citizens.

\section{Penal Sanction or Deterrent Measure}

House demolitions fulfill all of the elements of a penal measure. It is a sanction that causes intentional suffering to a person as a response to an illegal action. This kind of sanction ought to be considered punitive. This conclusion is supported by additional considerations:

8 Former Israeli Foreign Minister Abba Eban described the policy as a "desecration of Israel's heritage and a blatant violation of the legal and societal rules of the civilized world".

9 According to Simon, "The demolition policy may do more to inflame Palestinian defiance than to deter it. Palestinians perceive it as a gross injustice; it precipitates anger and humiliation rather than respect for the rule of law. Instead of providing a healthy basis for maintaining peace and order, the policy tends to reaffirm people's belief that they will not receive justice from an alien government". This was also the position of the professional committee, discussed above, that investigated the demolitions measure (the Shani Committee).

10 Moreover, the right to protection of property constitutes part of the Universal Declaration of Human Rights which states: "No one shall be arbitrarily deprived of his property". 
A. The Israeli Supreme Court, Israeli military and political leaders throughout the 1970s and 1980s characterized house demolitions as a "punishment" [17-19] ${ }^{11}$. Former brigadier general Shlomo Gazit argued that "the punishment must be immediately visible in order to achieve deterrence and that destroying the offender's home one day after the event produces a 'pillar of smoke' that everyone sees, hears and understands" ([4], p. 10) ${ }^{12}$.

B. Article 119 falls within a section of the Emergency Regulations, which deals with "miscellaneous penal provisions" (emphasis added) ([9], p. 481). Moreover, in several cases, Supreme Court Justice Aharon Barak analyzed the reasonableness of the commander's decision by examining the relationship between the severity of the offense and the severity of the applied measure [20]. This relationship between an action and the sanction's severity is one of the main characteristics of a punishment system ([5], p. 322).

A possible argument against this conclusion is that as an administrative body issues the sanction, it should therefore be considered administrative and not penal. This puts the cart before the horse. The fact that a demolition is issued by an administrative body does not make it administrative ([5], p. 323; [21], pp. 115, 130). The nature of the sanction should determine which type of body is authorized to apply it, and not the other way around. Defining a measure as punitive means that it may only be issued by a judicial body ([5], p. 323).

According to this analysis, the reasoning of the Supreme Court, according to which house demolitions are measures of deterrence and not punishment $[22-25]^{13}$, should be rejected.

The rationale of deterrence and prevention does not exclude the punitive nature of the measure. One of the main purposes of punishment is "general deterrence". Moreover, the overall, main and foremost purpose of criminal prohibitions is to deter the public from committing criminal offences ([5], pp. 322-23). As stated, a sanction that causes intentional suffering, damage or any other kind of worsening of a person's situation as a response to an illegal action ought to be considered a punitive measure.

The demolition measure meets all of these characteristics. The suffering caused to the occupants of the demolished house is not merely an incidental side effect of the sanction, nor is it similar to the suffering caused to the relatives of a prisoner as a result of their imprisonment [26] ${ }^{14}$. When the head

11 In a case involving the Association for Civil Rights in Israel, the Court repeated this approach and indicated that "everybody agrees that a demolition of a building is a tough and severe penalty measure. The preventive power which is concealed inside property demolition does not change the fact that the sanction is punitive" [20].

12 Former Brigadier General Shlomo Gazit served as Coordinator of Governmental Activities in the Administered Territories and worked closely with Moshe Dayan in the first years of the occupation.

13 The claim was raised for the first time by Justice Barak in Abu Allan Case and was presented later on in the Shukri Case, and since then has been used consistently by the court: "The authority which is given to the military commander by Article 19 is not an authority to execute a collective punishment; its activation is not designed to punish the appellant family members. The authority is administrative and its activation is meant to prevent and by this to maintain the public order".

14 This argument was raised by the court in the Daghlas case as follows: "The objective of Article 119 is to achieve the effect of deterrence, and such an effect, by nature, should be applied not only to the terrorist himself but also to those who surround him, certainly to the members of his family who reside with him...He should bear in mind that his despicable actions will not only harm himself, but they may also cause grave suffering to his family. In this respect 
of a family is detained, the suffering caused to the other family members is an inevitable side effect of the imprisonment, but it is not its purpose. The Annulment of the effect of the imprisonment on the family would not interfere with the purpose of the sanction, nor would it reduce its intended impact, which is focused primarily on the prisoner. On the other hand, the suffering caused to the occupants of the home, as a result of the demolition, is exactly the same suffering caused to the suspect of an offense, and is intended as such. It is an important element of the sanction and part and parcel of its main purpose. The impact on the other residents of the house is often a decisive factor in assessing how effective the sanction is in acting as a deterrent. In many cases, the suspect does not suffer from the demolition at all because they themselves were either killed, sentenced to life in prison, escaped from the area, or the house does not belong to them. It is quite often the case that the uninvolved residents of the house suffer more from its demolition than the suspect who is unable to use the house. In such cases, the only purpose served by the sanction is to cause suffering to the uninvolved inhabitants.

\section{Demolition of Houses-An Illegal Penal Sanction}

Since we are dealing with a penal sanction, several conditions must be met:

(1) According to the principles of criminal law, it must be imposed by a court, following a fair trial.

(2) The punishment must be based on personal liability.

(3) It should be consistent with the international prohibition on imposing a cruel and inhuman punishment ([3], pp. 373-74; [13], art. 5; [27,28]) ${ }^{15}$.

As already demonstrated, demolition of houses does not fulfill the two first requirements. It is also obvious that for persons uninvolved in the crime, it constitutes cruel and degrading treatment. Even in cases where the house being demolished was used solely by the suspect, it still should be considered a cruel and inhuman punishment:

A. The demolition sanction may be imposed in addition to any another judicial sanction that might be inflicted on the suspect after their conviction. When it is imposed, there is no consideration of a possible additional punishment in the future. It is therefore possible that once the later punishment is given, the combination of the two sanctions will be too harsh, as in such cases where the court later on sentences the suspect to life imprisonment.

B. As far as we know, this method of punishment is unique to Israel and is not employed in any other place in the world [29].

C. A person's home can be seen as an extension of a person's body-there is an intimate closeness between a person and their home. The person's home can be described as a space that

there is no difference between the demolition sanction and the imprisonment of the head of the family, a father of young children who will be left without a guardian and provider. Here too family members get hurt".

15 The International Convention on Civil and Political Rights (Hereinafter: ICCPR) includes such a prohibition. Israel ratified the ICCPR in 1991. Article 7 of the ICCPR cannot be derogated from under any circumstances. According to article 16 of the Convention against Torture, state parties to the convention "shall undertake to prevent in any territory under its jurisdiction other acts of cruel, inhuman or degrading treatment or punishment which do not amount to torture as defined in article I, when such acts are committed by or at the instigation of or with the consent or acquiescence of a public official or other person acting in an official capacity". 
covers the body and provides it with shelter and safety. Destroying this safe haven is akin to a physical punishment.

D. Demolitions affect different people in different ways. If the suspect is only a tenant in the house, the impact of the demolition on them is less severe than demolition of a house that the suspect invested all their life in building. Because of this inherent inequality, the sanction is arbitrary.

E. Moreover, the demolition of a person's house is akin to uprooting the person from their land. It is similar to eradicating the roots of a tree. This argument is augmented when dealing with Palestinians, where the land is an extremely important element in their identity, and uprooting them from the land is therefore especially traumatic.

\section{Demolition of Houses-A Collective Punishment}

Even if we accept the court's view that the demolition of houses is not a penal sanction, the sanction would still be considered illegal due to its violation of the principle of collective punishment, which applies to both criminal and administrative sanctions.

In article 4(2)(b) of the International Committee of the Red Cross (Hereinafter: ICRC) Commentaries on Protocol Additional II to the Geneva Conventions, which deals with fundamental guarantees to protect victims of Internal Armed Conflicts, it states:

"The concept of collective punishment...should be understood in its widest sense, and concerns not only penalties imposed in the normal judicial process, but also any other kind of sanction (such as confiscation of property) as the ICRC had originally intended. The prohibition of collective punishments was included in the article relating to fundamental guarantees by consensus (as opposed to the penal provisions). That decision was important because it is based on the intention to give the rule the widest possible scope, and to avoid any risk of a restrictive interpretation...In fact, to include the prohibition on collective punishments amongst the acts unconditionally prohibited by Article 4 is virtually equivalent to prohibiting 'reprisals' against protected persons" [30] ${ }^{16}$.

\subsection{Definition}

Collective punishment is defined as:

"Punishment which has been rendered without regard to due process of law and is imposed on persons who themselves have not committed the acts for which they are being punished" [30].

In order to classify a measure as collective punishment, two requirements must be satisfied:

(1) There must be a palpable connection between the offence and the punishment imposed.

(2) The suffering caused to innocent parties must be significant and not an inevitable side effect of the suffering of those persons guilty of the offense ([9], p. 491). 
Defining a house demolition as a penal sanction does not mean that every time the sanction is used, it is necessarily a collective punishment. In cases in which the house is owned solely by the offender, the demolition is a personal penalty. However, this is not the case when the house is demolished because only one of its residents is a suspect, and as a result of the demolition, unrelated people other than the suspect find themselves homeless ([5], p. 325). In such circumstances, the above requirements are fulfilled and the demolition constitutes a prohibited collective punishment. These circumstances exist in most of the demolition cases due to the fact that most Palestinians homes house more than one person ([4], p. 53; [31]) ${ }^{17}$. Moreover, as mentioned above, a commander may issue a demolition order against a house that is not owned by the suspected offender ([4], p. 53).

The prohibition on collective punishment is anchored in both international law and Israeli law ([7], p. 268).

\subsection{International Law}

International humanitarian law contains provisions that prohibit collective punishment ([3], p. 369). The 1907 Hague Regulations and the Fourth Geneva Convention offer the most substantial prohibition on collective punishments: Article 50 of the Hague Regulations states: "No general penalty, pecuniary or otherwise, shall be inflicted upon the population on account of the acts of individuals for which they cannot be regarded as jointly and severally responsible" [32]. Moreover, the first part of Article 33 of the Fourth Geneva Convention entitled "individual responsibility" states that "no protected person may be punished for an offense he or she has not personally committed. Collective penalties and likewise all measures of intimidation or of terrorism are prohibited" ([7], p. 268; [12], art. 33; [30], p. 225) ${ }^{18}$.

The 1907 Hague Regulations are unanimously considered to be customary international law [33]. Article 33(1) of the Fourth Geneva Convention is based on Article 50 of the customary Hague Regulations and thus should also be considered customary international law.

The prohibition against collective sanctions is not limited to international humanitarian law. The American Convention on Human Rights [34] ${ }^{19}$ and the African Charter on Human and Peoples' Rights [35] ${ }^{20}$ both contain provisions banning the use of collective punishment ([9], pp. 486, 490) ${ }^{21}$.

Human rights law does not explicitly prohibit "collective punishment" as such. Nevertheless, collective punishment can be considered a violation of the right to personal responsibility, the right to

17 In the Qarabsa Case, the demolition left 27 people homeless.

18 The Commentary on the Fourth Geneva Convention states, "This paragraph then lays a prohibition on collective penalties. This does not refer to punishments inflicted under penal law, i.e., sentences pronounced by a court after due process of law, but penalties of any kind inflicted on persons or entire groups of persons, in defiance of the most elementary principles of humanity, for acts these persons have not committed".

19 "Punishment shall not be extended to any person other than the criminal."

20 "Punishment is personal and can be imposed only on the offender."

21 The prohibition on collective punishment can be found in other international law provisions such as: Article 87 of the Third Geneva Convention, which protects prisoners of war, which prohibits "collective punishment for individual acts". In addition, the two additional protocols to the Geneva Conventions prohibit the imposition of collective punishment "at any time and in any place whatsoever". Moreover, Article 4(b) of the Statute of the International Criminal Tribunal for Rwanda expressly enumerates collective punishment as a crime for which persons may be prosecuted for by the tribunal. 
liberty and security of person, and the right to a fair trial [36] ${ }^{22}$. Moreover, it is a violation of human dignity. Denying the uninvolved their right to have a roof over their heads means using these people for the sole purpose of the deterrence of others. The persons uninvolved in the crime are not treated as purposes but rather as means to serve an external purpose, which in turn is a violation of their human dignity ([21], p. 128).

\subsection{Domestic Law}

On several occasions, Israeli law has challenged the legality of collective punishments and questioned its effectiveness. In 1964 the Knesset annulled the 1936 Collective Punishment Ordinance ${ }^{23}$ while stating:

"The mere possibility of imposing a collective sanction in a general manner on residents of a certain area, offends notions of justice as well as the fundamental postulates of contemporary legal culture" ([4], p. 57; [37]).

The Supreme Court applied similar reasoning for prohibiting collective punishment ([4], p. 57; [38,39]). In the Bargaining Chips case, dealing with administrative detention of Lebanese civilians who were held as "bargaining chips", Chief Justice Barak stated that a democratic society may hold a person in administrative detention only if such a person poses "a direct threat and real danger to the state" [37]. Otherwise, "the harm to liberty and dignity is so substantial and deep, that it is not to be tolerated in a liberty and dignity seeking state, even if the rational of national security led to undertaking such a step" ([40], para. 19). The court emphasized that the prohibition against inflicting harm on a person who has no personal responsibility is an absolute one ([40], para. 19) ${ }^{24}$.

\subsection{The Court's Approach to the Collective Punishment Argument}

The argument concerning the collective punishment nature of house demolitions was raised several times in front of the court, the last of which was several of months ago [41]. The Supreme Court rejected the argument and decided, more than once, that the demolition of houses does not constitute

22 The UN Human Rights Committee stated: "States parties may in no circumstances invoke article 4 of the Covenant as justification for acting in violation of humanitarian law or peremptory norms of international law, for instance by taking hostages, by imposing collective punishments, through arbitrary deprivations of liberty or by deviating from fundamental principles of fair trial, including the presumption of innocence".

23 The law authorized administrative bodies to impose collective fines on communities or town.

24 "The damage to liberty and dignity, in the administrative detention of a person who himself does not pose a threat to national security, is extremely severe, to the point where the interpreter is not entitled to presume that the statute intended to achieve such severe harm...the transition from the administrative detention of a person from whom a danger is posed to national security to the administrative detention of a person from whom no danger is posed to national security is not a 'quantitative' transition but a 'qualitative' transition. The state detains, via the executive branch, a person who committed no crime, and from whom no danger is posed, and whose entire 'wrongdoing' is in being a 'bargaining chip'. The harm to liberty and dignity is so substantive and deep, that it is not to be tolerated in a liberty and dignity seeking state, even if the rationales of national security lead to undertaking such a step...Each person will be detained based on their wrongdoing and each will be held in administrative detention based on their offense. One is not to detain in administrative detention any other than one that himself poses a risk, with his own actions, to national security..." (emphasis added). 
collective punishment ([4], pp. 64-65; [5], p. 326; [7], p. 269; [9], p. 496; [42]) ${ }^{25}$. In dismissing the argument, the courts denied the measure's punitive nature, and argued that as it is not an intentional infliction of harm on innocent people, it is therefore not a collective measure. The court also emphasized the measure's deterrent nature.

In their recent decision, the judges of the Supreme Court's rejected, yet again, the collective punishment argument, while emphasizing, as in the previous cases, the preventive nature of the method and its effective deterrence. In addition, Justice Rubinstein referred to article 53 of the fourth Geneva Convention that protects property rights and stated that the ban on destroying property does not apply in cases where the action is required for military needs. He then added (while referring to Professor E. Gross writings) that demolition of houses for the purpose of preventing future attacks is a military need indeed. He then concluded that the real test to check whether the demolition constitute an illegal collective punishment should be the proportionality test ([41], para. 23). In the same decision, justice Solberg emphasized that the small number of cases in which this measure was used proves that it is not a collective punishment ([41], para. 3). Moreover, justice Hayot added that the fact the commander, before ordering the demolition, can take into consideration the involvement of the family members (although he is not obliged to) proves that this measure is not a classic illegal collective measure ([41], para. 4).

As we discussed above, the court's approach is unpersuasive:

(1) Even assuming the measure is not punitive, it still constitutes a collective punishment [see Chapter 3].

(2) As shown above, it is a punitive sanction. The main purpose of house demolitions is to cause suffering to the offender's family, in the hopes that this suffering will deter others from committing similar crimes in the future ([5], p. 320).

(3) Justice Rubinstein's interpretation of the article does not match the wording of the article according to which destruction is rendered "absolutely necessary by military operations" (emphasis added). Punitive demolition of houses for deterrence purposes is not related to a "military operation" and is not absolutely necessary. It is therefore prohibited under international law.

(4) As for Justice Solberg's remark, the frequency of application of a measure has no effect on its nature.

(5) Justice Hayot's explanation is also not convincing. Granting the commander non-obligatory discretion does not neutralize the collective nature of the sanction. The measure remains applicable in cases where there was no involvement of family members.

\section{The Principle of Personal Responsibility}

Even if we accept the court's view, according to which house demolitions are not a collective punishment, it is clear that house demolitions violate the principle of "personal culpability". This

25 In Justice Heshin's dissent opinion [42], he argued that the claim against damage to residential units of the extended family that is beyond the area that the perpetrator themselves lived in "deserves a further study and discussion". Heshin began his discussion of this issue by establishing that "the guiding principle" is that "one must not impose collective punishment or collective sanctions", that "each of the petitioners, and himself alone, should be punished for his crime". His final conclusion was, however, less determined. Heshin in his final decision interpreted the prohibition on collective punishment as preventing the punishment of residents in separate living unit but not on persons who share one housing unit. 
principle is largely accepted in Israeli law ([4], p. 56) and in the court's jurisprudence ([4], pp. 56-57; [43]). According to this principle, no sanction of any kind (penal or otherwise) nor any liability should be imposed on a person, except on the basis of their personal culpability and the danger they pose to society. This should remain the case even if the sanction against innocents people have a deterrent effect potential ([5], p. 327; [21], p. 130), as the entire principle of personal culpability was created because of this potential for deterrence, and to therefore prevent the use of innocent people for deterrence purposes ([21], p. 130).

The basic assumption of the principle of responsibility is that liability and sanctions should not be imposed upon an individual unless the prohibited act can be attributed to them ([21], pp. 115, 129), i.e., an individual is responsible for their own actions and for their contributions to the actions of others ([4], p. 54). Imposing responsibility upon an uninvolved resident of a house for a crime of another in the absence of any culpability or threat of danger on their part is using them as a tool for achieving other purposes, and thus violates the principle of personal responsibility and the right to human dignity, as mentioned above ([40], para. 19).

\section{Conclusions}

The aim of the article is to show that the measure of house demolitions is a punitive sanction.

As such, its application fails to fulfill the basic requirements of penal responsibility: (1) It is applied by an administrative authority without due process before a court of law; (2) It constitutes cruel and inhuman punishment; and (3) The sanction intentionally inflicts hardship on innocent people, for the sake of general deterrence, and by doing so violates the principle of personal responsibility as a condition for imposing sanctions.

Alternatively, even if it is assumed that the measure is an administrative one and not penal in nature, it still violates the prohibition against collective punishment that applies to all kinds of sanctions, both administrative and penal. Even assuming arguendo that it is not a collective punishment, its impact on those uninvolved in the initial crime violates the principle of personal responsibility, which also applies to both administrative and penal sanctions.

The general lesson to be drawn is that the examination of the nature of sanctions should go beyond the labels that are attached to them. Labeling a measure "sanction" does not provide enough information to understand the sanction's true nature. Labels are sometimes deliberately used or rather misused in order to escape from the requirements stemming from the true essence of a sanction. It is the essence of the sanction, not how it is labeled, which truly defines it.

\section{Acknowledgements}

This article was written under the auspices of the Amnon Lipkin Shahak Program on National Security and Democracy at the Israel Democracy Institute.

\section{Author Contributions}

Lina Saba-Habech authored the first draft and then Prof. Kremnitzer added his comments and inputs which were incorporated into the final version. 


\section{Conflicts of Interest}

The authors declare no conflict of interest.

\section{References and Notes}

1. Brian Farrell. "Israeli Demolition of Palestinian Houses as a Punitive Measure: Application of International Law to Regulation 119." Brooklyn Journal of International Law 28 (2002-2003): 871-936.

2. Defense (Emergency) Regulations (Israel), 1945.

3. John Quigley. "Punitive Demolition of Houses: A Study in International Rights Protection." St. Thomas Law Review 5 (1992): 359-87.

4. Dan Simon. "The Demolition of Homes in the Israeli Occupied Territories." Yale Journal of International Law 19 (1994): 1-79

5. David Kretzmer. "Judicial Review of Demolition and Sealing of Houses in the Occupied Territories." In Klinghoffer Book on Public Law. Edited by Itzhak Zamir. Jerusalem: Faculty of Law, Hebrew University of Jerusalem, 1993, pp. 305-57.

6. Saskawil v. Military Commander of Judea and Samaria Region 34(1) P.D. 464 (Israel), 1979.

7. Usama R. Halabi. "Demolition and Sealing of Houses in the Israeli Occupied Territories: A Critical Legal Analysis.” Temple International \& Comparative Law Journal 5 (1991): 251-71.

8. Amos Guiora. "Transnational Comparative Analysis of Balancing Competing Interests in Counter-Terrorism." Temple International \& Comparative Law Journal 20 (2006): 363-94

9. Shane Darcy. "Punitive House Demolitions, the Prohibition of Collective Punishment, and the Supreme Court of Israel.” Penn State International Law Review 21 (2002): 477-507.

10. Ilan Kfir, and Abba Eban. "Blowing up Homes-A Desecration of Israel's Heritage." Ma'ariv, 1981, p. 6.

11. Divri Hakinesset [Knesset Protocols] 567 (Hebrew) (Israel), 1981.

12. Geneva Convention relative to the Protection of Civilian Persons in Time of War, 75 U.N.T.S. 287, Entered into Force 21 October 1950, art. 53.

13. Universal Declaration of Human Rights, G.A. res. 217A (III), U.N. Doc A/810 at 71, 1948.

14. Cordula Droege. "The Interplay between International Humanitarian Law and the International Human Rights Law in Situations of Armed Conflict." Israel Law Review 40 (2007): 310-55.

15. Concluding Observations on: Democratic Republic of Congo, U.N. Doc. CCPR/C/COD/CO/3 (26 April 2006) Legal Consequences of the Construction of a Wall in the Occupied Palestinian Territory, Advisory Opinion, 9 July 2004 I.C.J.

16. HCJ 3239/02, Marab v. IDF Commander in Judea and Samaria, IsrSC 57(2) 349.

17. HCJ 434/79 Sahwil v. IDF Commander in Judea and Samaria 34(1) P.D. 464 [1979] (Israel).

18. HCJ 361/82 Hamri v. IDF Commander in Judea and Samaria 36(3) P.D. 439 [1982] (Israel).

19. HCJ 358/88 The Association for Civil Rights in Israel v. Head of the IDF Central Command 43(2) P.D. 529 [1989] (Israel).

20. HCJ 361/82 Khamri v Military Commander of Judea and Samaria Region 36(3) P.D. 439 [1982] (Israel). 
21. Mordechai Kremnitzer, and Tatjana Hornle. "Human Dignity and the Principle of Culpability." Israel Law Review 44 (2011): 115-41.

22. HCJ 878/89 Al Raqeb v. Military Commander of Gaza Region [1990] (unpublished) (Israel).

23. HCJ 387/89 Rajabi v. Military Commander of Judea and Samaria Region 43(3) P.D. 177, 179 [1989] (Israel).

24. HCJ 126/83 Abu Allan v. Minister of Defense 37(2) P.D. 169 [1983] (Israel).

25. HCJ 798/89 Shukri v. Minister of Defense [1990] (unpublished) (Israel).

26. HCJ 698/85 Daghlas V. IDF Commander in Judea and Samaria 40(2) P.D. 42 [1986], para. 44 (Israel).

27. International Covenant on Civil and Political Rights, G.A. res. 2200A (XXI), 21 U.N. GAOR Supp. (No. 16) at 52, U.N. Doc. A/6316 (1966), 999 U.N.T.S. 171, Entered into Force 23 March 1976, art. 7.

28. Convention against Torture and Other Cruel, Inhuman or Degrading Treatment or Punishment, U.N. Doc. A/39/51 (1984), 1465 U.N.T.S. 85, Entered into Force 10 December 1984, art. 16.

29. B'Tselem. "The Sealing and Demolition of Houses as a Means of Punishment in the West Bank and Gaza-A Report.” November 1990. Available online: http://www.btselem.org/sites/default/ files/hrysvt_ntymvt_btym_kmtsy_nyshh.pdf (accessed on 27 January 2015).

30. Oscar M. Uhler, Henri Coursier, Frederic Siordet, Roger Boppe, Claude Pilloud, Rene-Jean Wilhelm, and Jean-Pierre Schoenholzer. ICRC Commentary to the Fourth Geneva Convention. Edited by Jean S. Pictet. Geneva: International Committee of the Red Cross, 1958.

31. HCJ 2665/90 Qarabsa v. Minister of Defense [1990] (unpublished) (Israel).

32. International Committee of the Red Cross (ICRC). "Convention (IV) respecting the Laws and Customs of War on Land and its annex: Regulations concerning the Laws and Customs of War on Land." Available online: https://www.icrc.org/applic/ihl/ihl.nsf/INTRO/195 (accessed on 21 May 2015).

33. Adam Roberts, and Richard Guelff. Documents on the Laws of War, 3rd ed. Oxford and New York: Oxford University Press, 2000, pp. 179-94.

34. American Convention on Human Rights, 1144 U.N.T.S. 123, Entered into Force 18 July 1978, art. 5.

35. African Charter on Human and Peoples' Rights, 21 ILM 58, Entered into Force 21 October 1986, art. 7.

36. UN Human Rights Committee, General Comment No. 29 (Article 4 of the International Covenant on Civil and Political Rights) (§ 3809), para. 11.

37. 610 Bill 165 (18 May 1964) (Israel).

38. CrimA 325/64 Attorney General v. Yarkoni 18(4) P.D. 20, 46 (Israel), 1964.

39. CrimA 129/54 Goldstein v. Attorney General 10 P.D. 505, 540 (Israel), 1956.

40. CrimFH 7048/97 Anonymous (Lebanese citizens) v Minister of Defense, [2000] (Israel).

41. HCJ 8091/14 Hamoked: Center for the Defence of the Individual et al. v. Minister of Defense et al.

42. HCJ 5359/91 Khizran v. Military Commander of Judea and Samaria Region 46(2) P.D. 151, Justice Heshin, dissenting opinion (Israel), 1992.

43. CrimA 6147/92 State of Israel v. Cohen 48(1) P.D. 62, 67-76 (Israel), 1993.

(C) 2015 by the authors; licensee MDPI, Basel, Switzerland. This article is an open access article distributed under the terms and conditions of the Creative Commons Attribution license (http://creativecommons.org/licenses/by/4.0/). 